\title{
Karyotypes and genome size of Adonis amurensis and Adonis apennina (Ranunculaceae) from Asian Russia
}

\author{
E. Yu. Mitrenina ${ }^{1 *}$, A. S. Erst ${ }^{1,2}$, M. V. Skaptsov ${ }^{3}$, T. V. Leonova ${ }^{4}$, T. N. Veklich ${ }^{5}$, \\ O. A. Chernysheva ${ }^{6}$, A. N. Luferov ${ }^{7}$, W. Wang ${ }^{8}$ \\ ${ }^{1}$ National Research Tomsk State University, 36 Lenin Ave., Tomsk 634050, Russia \\ ${ }^{2}$ Central Siberian Botanical Garden SB RAS, 101 Zolotodolinskaya St., Novosibirsk 630090, Russia \\ ${ }^{3}$ Altai State University, 61 Lenin Ave., Barnaul 656049, Russia \\ ${ }^{4}$ Katanov Khakass State University, 90 Lenin Ave., Abakan 655017, Russia \\ ${ }^{5}$ Amur Branch of Botanical Garden-Institute FEB RAS, Ignatievskoe Road, 2 km, Blagoveshchensk 675000, \\ Russia \\ ${ }^{6}$ Siberian Institute of Plant Physiology and Biochemistry SB RAS, 134 Lermontov St., Irkutsk 664033, Russia \\ ${ }^{7}$ Federal State Autonomous Educational Institution of Higher Education I.M. Sechenov First Moscow State \\ Medical University of the Ministry of Health of the Russian Federation, 8 Izmailovsky Ave., 105043 Moscow, \\ Russia \\ ${ }^{8}$ Institute of Botany of the Chinese Academy of Sciences, 20 Nanxincun, Xiangshan, Beijing 100093, China \\ Corresponding author Email: emitrenina@gmail.com
}

Received: 06.01.2021. Accepted 11.02.2021

\begin{abstract}
The karyotypes of Adonis amurensis from Amur Oblast,' and Adonis apennina from Altai Republic, Khakassia Republic, and Irkutsk Oblast' have been investigated. The karyotype formula was obtained as $2 n=2 x=16=8 \mathrm{~m}+8 \mathrm{sm}(4 \mathrm{sat})$ for all specimens. We estimated karyotype asymmetry through the calculation of the Coefficient of Variation of Chromosome Length (CV $\mathrm{CL}_{\text {) }}$, Coefficient of Variation of Centromeric Index $\left(\mathrm{CV}_{\mathrm{CI}}\right)$, and Mean Centromeric Asymmetry (McA), and determination of Stebbins asymmetry index. The chromosome set of Adonis amurensis was found to be more symmetrical than the chromosome set of Adonis apennina. The average absolute nuclear DNA content (2C-value) was originally determined for Adonis amurensis and Adonis apennina by flow cytometry and attained on average 20.38 pg and 17.29 pg, respectively.
\end{abstract}

Keywords: Adonis L., chromosomes, 2C-value, karyotype, nuclear DNA content, Ranunculaceae.

\section{Introduction}

The genus Adonis L. is composed of perennial and annual herbaceous plants included in the tribe Adonideae T. Duncan\&Keener under the subfam. Ranunculoideae of the Ranunculaceae Juss. family (Tamura, 1991; Luferov, 2004; Nishikawa \& Kadota, 2006; Ren et al., 2009). According to various authors, the genus includes 40-50 (Poshkurlat, 2000) or 47-50 species (Luferov, 2018) distributed mainly in the extratropical zones of Eurasia. Approximately 26-30 species grow in the northern temperate zone, including Asia, Europe, and North America, and some annual plants are known to be distributed from Southwest Asia to North Africa, as well as along the shores of the Mediterranean (Meusel et al., 1965; Cronquist, 1981; Wang, 1994a; 1994b; Son et al., 2016). In Russia, nine species are known, which include six perennials and three annuals. This genus's representations are found on plains and uplands in forest, meadow, steppe cenoses, limestone outcrops, and rocky outcrops (Luferov, 2020).

The genus Adonis is characterized by rhizomatous perennials or annual herbaceous plants with erect flowering shoots. Leaves basal and cauline (cauline often absent at flowering time), proximal leaves petiolate, distal leaves sessile; cauline leaves alternate. Leaf blade 1-3-pinnately dissected, segments narrowly linear, margins entire or with the occasional tooth. Inflorescences terminal, flowers solitary; bracts absent. Flowers bisexual, radially symmetric; sepals 5-8, not persistent in fruit, nearly colorless or green, plane, obovate, 6-22 mm, apex erose; petals 3-20, distinct, yellow, red or white, often striped or basally darkened with black, purple, or blue, plane, oblanceolate, 8-35 mm; nectary absent; stamens 15-80; filaments filiform; 
staminodes absent between stamens and pistils; pistils ca. 20-50, simple; ovule 1 per pistil; style present. Fruits achenes, aggregate, sessile, nearly globose, sides veined or rugose; persistent style terminal, straight or strongly curved (Parfitt, 1993). The somatic chromosome numbers are known for most species of Adonis (Rice et al., 2015). The basic chromosome number for the genus is $x=8$. Perennial species tend to have the diploid number of chromosomes $2 n=16$ (Shlangena, 1976). However, there are also polyploid races such as Adonis amurensis Regel et Radde (Kurita, 1955; Nishikawa \& Ito, 1979; Nishikawa, 1989). Annual species tend to have higher numbers of chromosomes, such as $2 n=32 ; 48$ (Shlangena, 1976). There are less data on the structure of chromosome sets, although many species have been studied in detail. In this study, we present data on chromosomal sets of two species of Adonis growing in Russia: Adonis amurensis from Amur Oblast' and Adonis apennina L. from Altai Republic, Khakassia Republic, and Irkutsk Oblast. We appear to be the first to provide data on the nuclear DNA content (2C-values) of these species.

Adonis amurensis Regel et Radde is referred to the section Adonanthe W.T. Wang, subsection Amurenses (Poschkurl.) M.H. Hoffm. and characterized by $15 \mathrm{~cm}$ tall at flowering, up to $30-40 \mathrm{~cm}$ high at fruiting time, with a short rhizome and numerous blackbrown adventitious roots. Shoots erect or ascending, simple or branching, with 3-6 scaly leaves up to $3 \mathrm{~cm}$ long, single-flowered, occasionally multi-flowered, straight or geniculate stems; imparipinnate, 4-pinnatifid with narrow-lanceolate acute or obtuse segments, shortly pubescent basal leaves; smaller, 3(2) order dissection upper leaves: 5 (rarely up to 7), greenish-gray, lavender sepals 4; 5-12 (sometimes up to 15), 1.2-2.5 cm long, 0.3-0.8 cm wide, oblong-elliptical, rounded at the apex and narrowed at the base, yellow petals; 3.5-5.0 mm long, greenish-brown, densely pubescent. Stylodia is located almost at the ovary's apex or shifted to the dorsal suture stamens (Fig. 1A). This species is distributed in Russian Far East: Amur Oblast, Jewish Autonomous Oblast', Khabarovsk and Primorsky Territories, Sakhalin Island, southern Kuril Islands: Kunashir, Shikotan, Iturup, North-East China, Korea Peninsula, North Japan: Hokkaido. - Deciduous forests, glades, meadows, rocky outcrops (Luferov, 2004).
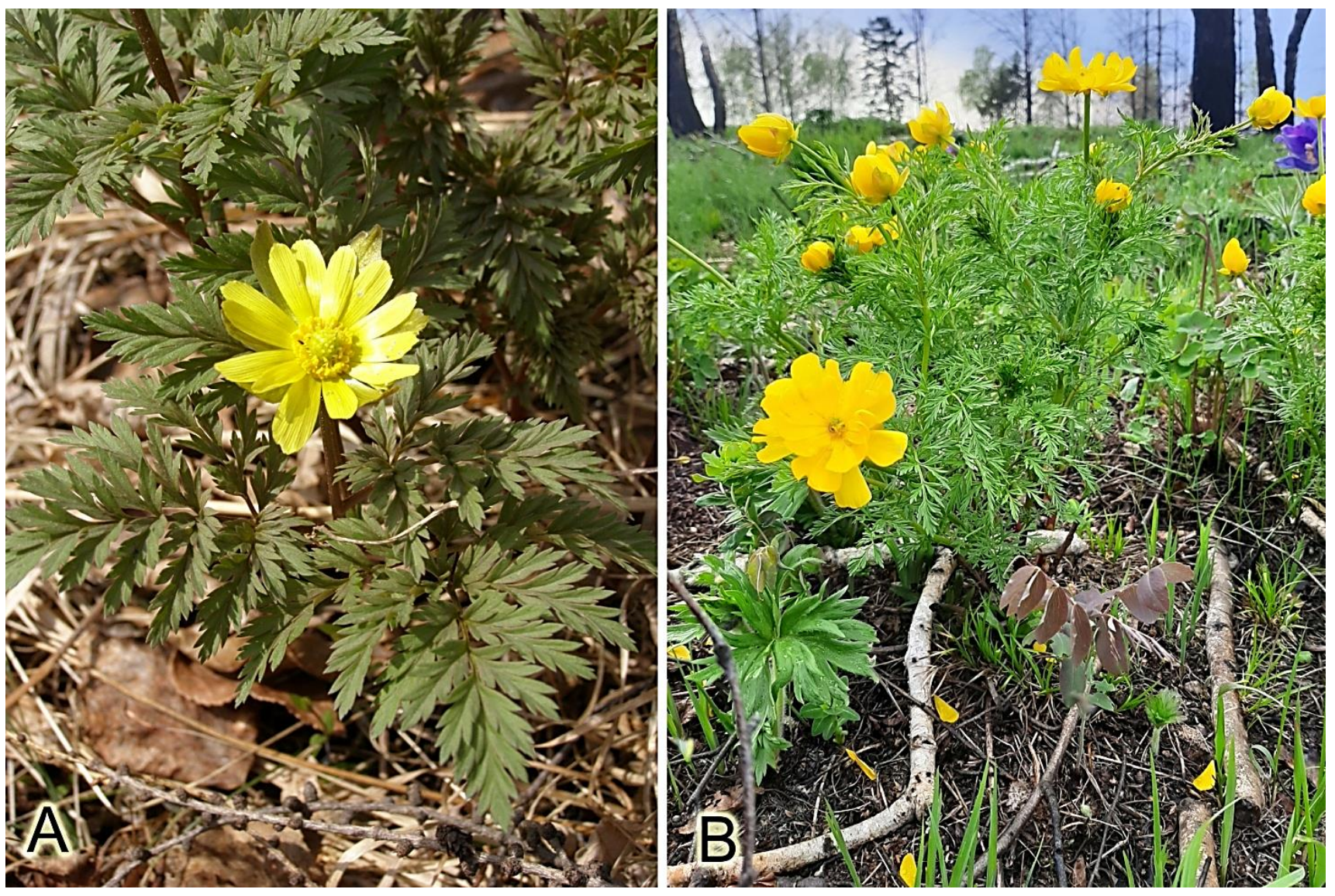

Fig. 1. A - Adonis amurensis (photo by Tatiana Veklich); B - Adonis apennina (photo by Olga Chernysheva).

Adonis apennina L. is referred to the section Adonanthe W.T. Wang, subsection Vernales Poschkurl. and characterized by thick short rhizomes and black-brown adventitious roots; erect or ascending, simple or branching, up to $15 \mathrm{~cm}$ high at flowering, up to 30-40 cm high at fruiting, with 3-6 scaly leaves up to $3 \mathrm{~cm}$ long, one-flowered or multi-flowered stems (extremely rarely); straight or slightly curved, rounded, slightly ribbed stem; imparipinnate, 2- or 3-pinnatifid, with narrow lanceolate, acute or obtuse segments; upper leaves are smaller, second-order dissection basal leaves; 5 (rarely up to 7), greenish-gray, lavender sepals; 5-12 (sometimes up to 15), 2.0-3.0 cm long, 0.5-1.0 cm wide, obovate or rounded and narrowed at the base, mostly overlapping, yellow petals; numerous, 3.5-5.0 mm long, greenish-brown, densely pubescent stamens; almost at the apex of the ovaries, often more or less displaced to the dorsal suture stylodia (Fig. 1B). This species is distributed in the north-eastern part of European Russia, West, Middle and East Siberia, Russian Far East: south-west of Amur Oblast', Middle Asia, Mongolia, China. - Dry meadows, forest glades, and among forbs (Poshkurlat, 2000). In some publications, Adonis apennina is referred to as Adonis sibirica Patrin ex Ledeb. (Wang, 1994b), but the first name is nomenclature priority (Sennikov, 1998). 


\section{Materials and Methods}

All the studied plants have been collected in their natural localities. The vouchers are listed in Table 1. Adonis stout rhizomes were stored in wet moss before having young leaves.

\section{Karyotyping}

Newly formed $0.5-1.0 \mathrm{~cm}$ long leaves were excised and pretreated in $0.5 \%$ aqueous colchicine solution for $3-4 \mathrm{~h}$ at room temperature. After that, they were fixed in a mixture of $96 \%$ ethanol and glacial acetic acid (3:1). Leaves were stained with $1 \%$ aceto-hematoxylin, and the karyotype was investigated by the squash method (Smirnov, 1968). Chromosomes were counted in 20-30 mitotic cells for each species. Mitotic metaphase chromosome plates were studied using an Axio Star microscope (Carl Zeiss, Munich, Germany) and photographed using an Axio Imager A.1 microscope (Carl Zeiss, Germany) with AxioVision 4.7 software (Carl Zeiss, Germany) and AxioCam MRc5 CCD-camera (Carl Zeiss, Germany) at 1000× magnification in the Laboratory for Ecology, Genetics and Environmental Protection (Ecogene), National Research Tomsk State University. KaryoType software (Altinordu et al., 2016) was used for karyotyping, and Adobe Photoshop CS5 (Adobe Systems, USA) and Inkscape 0.92 (USA) were used for image editing. Karyotype formulas were derived based on measurements of mitotic metaphase chromosomes taken from photographs. We studied metaphase plates with the most condensed chromosomes.

The measurements were performed on five metaphase plates. The symbols used to describe the karyotypes corresponded to those of Levan et al. (1964): $\mathrm{m}$ = median centromeric chromosome with an arm ratio of 1.0-1.7 (metacentric chromosome); sm = submedian centromeric chromosome with an arm ratio of 1.7-3.0 (submetacentric chromosome); st $=$ subterminal centromeric chromosome with an arm ratio of 3.0-7.0 (subtelocentric chromosome); $\mathrm{t}=$ terminal centromeric chromosome with an arm ratio of 7.0- (acrocentric or telocentric chromosome); $\mathrm{T}$ = chromosome without an obvious short arm, i.e., with an arm ratio of $\infty$. Mean values of centromeric indices $(\mathrm{Cl})$, mean chromosome length $(\mathrm{CL})$, and relative chromosome length ( $\mathrm{RL}$ ) for each chromosome pair, total haploid length ( $T H L)$, and mean chromosome length of the set (mean $C L$ ) were determined.

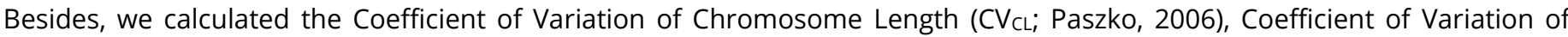
Centromeric Index (CV Cl; Paszko, 2006), Mean Centromeric Asymmetry (McA; Peruzzi \& Eroğlu, 2013), and determined Stebbins asymmetry index (Stebbins, 1971).

\section{Flow cytometry}

Flow cytometry with propidium iodide (PI) staining was used to determine the absolute nuclear DNA content. Silica gel-dried leaf material was chopped with a sharp razor blade in a $1 \mathrm{ml}$ cold nuclei extraction buffer composed of $50 \mathrm{mM} \mathrm{Hepes,} 10 \mathrm{mM}$ sodium metabisulphite, $10 \mathrm{mM} \mathrm{MgCl} 2,0.5 \%$ polyvinylpyrrolidone, $0.1 \%$ bovine serum albumin, $0.3 \%$ Tween 20, 0.2\% Triton X$100,50 \mu \mathrm{g} / \mathrm{ml}$ RNase, $1 \mu \mathrm{g} / \mathrm{ml} \beta$-mercaptoethanol, and $50 \mu \mathrm{g} / \mathrm{ml}$ propidium iodide (PI). The samples were filtered through 50 $\mu \mathrm{m}$ nylon membranes into sample tubes and incubated in the dark at $4{ }^{\circ} \mathrm{C}$ for $15 \mathrm{~min}$. The samples were measured using a Partec CyFlow PA flow cytometer equipped with a green laser at $532 \mathrm{~nm}$ wavelength. The absolute nuclear DNA content, the 2C-value according to Greilhuber et al. (2005), was calculated as the ratio of the mean fluorescence intensity of the sample nuclei to that of an internal standard multiplied by the total nuclear DNA content of the standard. A possible effect of secondary metabolites on the binding of the intercalating dye was evaluated by measuring the fluorescence of Allium fistulosum L. leaf samples prepared as described above, but with the addition of the supernatant from Adonis samples centrifuged without PI (Erst et al., 2020b; Mitrenina et al., 2020). The samples were measured three times at 10 min intervals. If the $A$. fistulosum peak showed no variation in the average values of the detection channels, the effect of secondary metabolites was considered negligible. Allium fistulosum L., 2C = 23.50 pg was used as an internal standard (Doležel et al., 1992; Ricroch et al., 2005; Smirnov et al., 2017). We used the Statistica 8.0 software (StatSoft, Inc.), Flowing Software 2.5.1 (Turku Centre for Biotechnology), and CyView software (Partec, GmbH) for data analyses. Flow cytometry was performed at the South-Siberian Botanical Garden, Altai State University (Barnaul, Russia).

\section{Results and Discussion}

The chromosome sets of Adonis amurensis from Amur Oblast and Adonis apennina from Altai Republic, Khakassia Republic, and Irkutsk Oblast' have been investigated the first time (Table 1). Adonis chromosomes are quite large and belong to the Ranunculus-type (Langlet, 1932). The somatic chromosome numbers are determined as $2 n=16$ for almost all the plants studied. An exception was one plant of $A$. apennina from the Kuytunsky Raion of Irkutsk Oblast' with chromosome number $2 n=24$. According to current scientific data, $A$. amurensis shows different chromosome numbers. Thus, plants with $2 n=16$ (Starodubtsev, 1985; Volkova et al., 2020) and $2 n=32$ (Starodubtsev, 1989) have been identified in Primorsky Krai and Sakhalin Island. For Japan, chromosome numbers are given $2 n=16 ; 24 ; 32 ; 40$ (Kurita, 1955; Nishikawa \& Ito, 1979; Nishikawa, 1989), while for Korea are $2 n=16 ; 32$ (Lee, 1967), and $2 n=16$ for China (Wang \& Liu, 1988). Nishikawa \& Ito (1979) suggested that the origin of plants with $2 n=24$ was presumably a hybridization between a $2 n=16$ plant and a $2 n=32$ plant. For Adonis apennina, only the somatic chromosome number of $2 n=16$ is known (Shlangena, 1976; Schrager \& Malakhova, 1978; Schrager, 1980; Lavrenko \& Serditov, 1985). The unique plant with $2 n=24$ we discovered was formed by merging the gamets with a reduced and not reduced chromosome number, rather than by hybridizing plants of different cytotypes, as in the case of $A$. amurensis. 
Table 1. Chromosome numbers $(2 n)$ and $2 \mathrm{C}$-values ( $2 \mathrm{C} \pm \mathrm{SD})$ in Adonis amurensis and Adonis apennina.

\begin{tabular}{|c|c|c|c|}
\hline Species & Voucher information & $2 n$ & $\begin{array}{c}2 C \text {-value } \\
(2 \mathrm{C} \pm \mathrm{SD}, \mathrm{pg})\end{array}$ \\
\hline $\begin{array}{l}\text { Adonis amurensis } \\
\text { Regel \& Radde }\end{array}$ & $\begin{array}{l}\text { Russia, Amur Oblast', Bureysky Raion, left } \\
\text { riverside of the Sinel' River, birch-larch-aspen } \\
\text { forest, 50.246611, 130.186194, } 204 \text { m alt., } \\
\text { 06.05.2020. Veklich T.N. }\end{array}$ & 16 & $20.05 \pm 0.92$ \\
\hline $\begin{array}{l}\text { Adonis amurensis } \\
\text { Regel \& Radde }\end{array}$ & $\begin{array}{l}\text { Russia, Sakhalin Oblast', Kunashir Island, near } \\
\text { Zmeinyj River, tall grass, 44.010380, 145.674850, } \\
33 \text { m alt., 18.05.2020. Linnik E.V. }\end{array}$ & 16 & $20.71 \pm 1.20$ \\
\hline Adonis apennina $\mathrm{L}$. & $\begin{array}{l}\text { Russia, Altai Republic, Shebalinsky Raion, P-256 } \\
\text { Gorno-Altaysk - Tashanta Road, between } \\
\text { Topuchaya Village and the Seminsky Pass, on the } \\
\text { south-western slope of the road, 51. 092222, } \\
85.590278,1320 \text { m alt., } 03.06 .2020 \text {. Erst A.S., Erst } \\
\text { T.V., Boltenkov E.V. No. } 8\end{array}$ & 16 & $17.67 \pm 0.62$ \\
\hline Adonis apennina $\mathrm{L}$. & $\begin{array}{l}\text { Russia, Altai Republic, Ust-Kansky Raion, near Ust- } \\
\text { Kan Village, the edge of the larch forest, the } \\
\text { northern slope, } 50.934722,84.729722,1020 \mathrm{~m} \\
\text { alt., } 04.06 .2020 \text {. Erst A.S., Erst T.V., Boltenkov E.V. } \\
\text { No. } 9\end{array}$ & 16 & $17.16 \pm 0.25$ \\
\hline Adonis apennina $\mathrm{L}$. & $\begin{array}{l}\text { Russia, Altai Republic, Ust-Kansky Raion, Ust-Kan - } \\
\text { Tuecta road, descent from the Yabogansky Pass, } \\
\text { around the Tahoy River, Penthaphylloides } \\
\text { fritocosa bushes subalpine meadow, } 50.851944 \text {, } \\
85.241944,1320 \text { m alt., } 05.06 .2020 \text {. Erst A.S., Erst } \\
\text { T.V., Boltenkov E.V. No. } 15\end{array}$ & 16 & $17.55 \pm 0.51$ \\
\hline Adonis apennina $\mathrm{L}$. & $\begin{array}{l}\text { Russia, Altai Republic, Kosh-Agach Raion, near } \\
\text { Aktash Village, the edge of the larch forest, } \\
50.275278,87.673056,1430 \mathrm{~m} \text { alt., } 07.06 .2020 . \\
\text { Erst A.S., Erst T.V., Boltenkov E.V. No. } 31\end{array}$ & 16 & NA \\
\hline Adonis apennina $\mathrm{L}$. & $\begin{array}{l}\text { Russia, Khakassia Republic, Ordzhonikidze Raion, } \\
\text { near Sarala Village, 54.870972, 89.351917, } 511 \text { m } \\
\text { alt., 16.05.2020. Leonova T.V. No. } 7.1\end{array}$ & 16 & $17.02 \pm 0.41$ \\
\hline Adonis apennina $\mathrm{L}$. & $\begin{array}{l}\text { Russia, Irkutsk Oblast', Tulunsky Raion, in } 0.5 \text { km } \\
\text { south-west of Azei Village, road side, } 54.447117 \text {, } \\
100.7811,477 \text { m alt., 12.05.2020. Chernysheva } \\
\text { O.A. No. } 6\end{array}$ & 16 & NA \\
\hline Adonis apennina $\mathrm{L}$. & $\begin{array}{l}\text { Russia, Irkutsk Oblast', Kuytunsky Raion, in } 7 \text { km } \\
\text { southeast of Mintagui Village, at the federal } \\
\text { highway P55, birch forest after burning, } \\
\text { 54.405467, 101.356383, } 558 \text { m alt., 12.05.2020, } \\
\text { Chernysheva O.A. No. } 7\end{array}$ & $\begin{array}{l}16 \\
24\end{array}$ & $17.41 \pm 0.54$ \\
\hline Adonis apennina $\mathrm{L}$. & $\begin{array}{l}\text { Russia, Irkutsk Oblast', Zalarinsky Raion, } 7 \text { km } \\
\text { southeast of Zalari Village, at the federal highway } \\
\text { P55, sparse birch forest, after burning, } 53.558517 \text {, } \\
\text { 102.578083, } 437 \text { m alt., } 12.05 .2020 \text {, Chernysheva } \\
\text { O.A. No. } 8\end{array}$ & 16 & $17.23 \pm 0.41$ \\
\hline Adonis apennina $\mathrm{L}$. & $\begin{array}{l}\text { Russia, Irkutsk Oblast', Usol'sky Raion, left bank of } \\
\text { the Kitoy River, Pine forest, 52.453817, 103.6558, } \\
441 \text { m alt., 20.05.2020, Chernysheva O.A. No. } 27\end{array}$ & 16 & $16.96 \pm 0.50$ \\
\hline
\end{tabular}

Note. NA - data not available.

The structure of the chromosome sets of Adonis amurensis and $A$. apennina is similar. The karyotype formula is $2 n=2 x=16=$ $8 \mathrm{~m}+8 \mathrm{sm}$ (4sat) for both species. An extensive karyomorphological analysis was carried out for $A$. amurensis from Amur Oblast' and A. apennina from two localities - Altai Republic (Kosh-Agach Raion, No. 31) and Irkutsk Oblast' (Usol'sky Raion, No. 27) (Tables 2, 3; Fig. 2). The obtained average lengths of chromosomal arms were used to draw idiograms. The chromosomes were divided into two groups according to the morphology (metacentric and submetacentric ones), and within the group, they have been arranged as the chromosome length decreases. In general, our results are consistent with those presented in other studies. The karyotype of $A$. amurensis was previously studied for plants with $2 n=24$ from Japan (Kurita, 1955). It was found 
that the karyotype equally consists of isobrachial and heterobrachial chromosomes. The difference in the karyotype formulas presented in this study and the manuscript by M. Kurita is due to different chromosome nomenclature. M. Kurita classified heterobrachial chromosomes as subtelocentric, while we classified them as submetacentric ones. The karyotype of Adonis amurensis with $2 n=16$ from Primorsky Krai and Sakhalin Island has been recently described (Volkova et al., 2020). The karyotype formula is similar to our result, but there are some differences in some chromosomes' relative length. All submetacentric chromosomes are shorter than metacentric ones in the karyotypes of plants from the Primorsky Krai and Sakhalin Island. While in karyotype plants from Amur Oblast' the shortest metacentric chromosome (IV pair) is shorter than several submetacentric chromosomes (V-VII pairs). These differences are likely related to the level of condensation of the chromosomes studied. We studied more compact chromosomes because the total length of the set in our study was lower than that in another research. The chromosome sets of Adonis apennina were previously studied for Kemerovo, Tomsk, and Krasnoyarsk Oblast' for plants with $2 n=16$ (Schrager \& Malakhova, 1978; Schrager, 1980). The plants from the Altai Republic, Khakassia Republic, and Irkutsk Oblast' have been investigated in this study. There are no significant differences in the karyotype structure between the populations studied and the previous works' results. There are slight variations in the relative length of chromosomes and centromeric indices. Up to four satellite chromosomes were presented in all the investigated karyotypes. Satellites were small and single or double. They were not found in all cells related to the level of chromosome compaction of the metaphase plates studied. In the studied populations of Adonis apennina and $A$. amurensis we have not detected polymorphism on the morphology of satellite chromosomes, as previously shown (Schrager, 1980; Volkova et al., 2020).

In addition to the basic karyomorphological parameters, we estimated some karyotype asymmetry indices (Table 3). The qualiquantitative Stebbins asymmetry index (1971) was 2A for Adonis amurensis and 3A for A. apennina. The chromosome number with an arm ratio $<2$ was five pairs in $A$. amurensis and four pairs in $A$. apennina. Three parameters detecting interchromosomal and intrachromosomal karyotype asymmetries, $\mathrm{CV}_{\mathrm{CL}}$ - Coefficient of Variation of Chromosome Length, $\mathrm{CV}_{\mathrm{Cl}}$ - Coefficient of Variation of Centromeric Index (Paszko, 2006), and McA - Mean Centromeric Asymmetry (Peruzzi \& Eroğlu, 2013), were close in A. apennina from two investigated populations. Insignificant differences are related to the degree of condensation of chromosomes of the plates studied. The intrachromosomal and interchromosomal asymmetries' parameters were lower in $A$. amurensis, which means that this species has a more symmetric karyotype than A. apennina.

Table 2. Karyomorphological parameters of Adonis amurensis and Adonis apennina.

\begin{tabular}{|c|c|c|c|c|c|c|}
\hline Species & $\begin{array}{l}\text { Chromosome } \\
\text { pair }\end{array}$ & $C L, \mu \mathrm{m}$ & r & $\mathrm{Cl}$ & $\mathrm{RL}, \%$ & $\begin{array}{c}\text { Chromosome } \\
\text { type }\end{array}$ \\
\hline & I & $6.30(0.27)$ & $1.06(0.02)$ & 0.49 & 7.15 & $\mathrm{~m}$ \\
\hline & II & $5.85(0.28)$ & $1.22(0.06)$ & 0.45 & 6.64 & $\mathrm{~m}$ \\
\hline & III & $5.60(0.36)$ & $1.08(0.05)$ & 0.48 & 6.35 & $\mathrm{~m}$ \\
\hline Adonis & IV & $4.98(0.29)$ & $1.16(0.06)$ & 0.46 & 5.65 & $\mathrm{~m}$ \\
\hline amurensis & V & $5.69(0.36)$ & $1.91(0.11)$ & 0.34 & 6.46 & sm \\
\hline \multirow[t]{6}{*}{ (Amur Oblast') } & VI & $5.49(0.25)$ & $2.27(0.10)$ & 0.31 & 6.23 & $\mathrm{sm}$ \\
\hline & VII & $5.21(0.21)$ & $2.04(0.14)$ & 0.33 & 5.91 & sm \\
\hline & VIII & $4.93(0.14)$ & $2.08(0.14)$ & 0.33 & 5.60 & $\mathrm{sm}$ \\
\hline & I & $6.10(0.42)$ & $1.06(0.03)$ & 0.49 & 7.27 & $\mathrm{~m}$ \\
\hline & ॥ & $6.10(0.35)$ & $1.17(0.04)$ & 0.46 & 7.27 & $\mathrm{~m}$ \\
\hline & III & $5.55(0.30)$ & $1.10(0.03)$ & 0.48 & 6.62 & $\mathrm{~m}$ \\
\hline Adonis & IV & $4.72(0.11)$ & $1.18(0.03)$ & 0.46 & 5.63 & $\mathrm{~m}$ \\
\hline apennina & V & $5.11(0.30)$ & $2.34(0.08)$ & 0.30 & 6.09 & $\mathrm{sm}$ \\
\hline \multirow{5}{*}{$\begin{array}{c}\text { (Altai Republic, } \\
\text { No. } 31 \text { ) }\end{array}$} & VI & $4.99(0.29)$ & $2.61(0.08)$ & 0.28 & 5.95 & $\mathrm{sm}$ \\
\hline & VII & $4.72(0.21)$ & $2.54(0.13)$ & 0.28 & 5.63 & $\mathrm{sm}$ \\
\hline & VIII & $4.65(0.27)$ & $2.38(0.13)$ & 0.30 & 5.54 & sm \\
\hline & I & $6.62(0.20)$ & $1.29(0.06)$ & 0.44 & 7.29 & $\mathrm{~m}$ \\
\hline & II & $6.42(0.22)$ & $1.04(0.02)$ & 0.49 & 7.07 & $\mathrm{~m}$ \\
\hline Adonis & III & $5.91(0.23)$ & $1.13(0.06)$ & 0.47 & 6.51 & $\mathrm{~m}$ \\
\hline apennina & IV & $5.09(0.19)$ & $1.25(0.06)$ & 0.45 & 5.61 & $\mathrm{~m}$ \\
\hline (Irkutsk & V & $5.73(0.51)$ & $2.15(0.13)$ & 0.32 & 6.31 & $\mathrm{sm}$ \\
\hline Oblast', & VI & $5.49(0.17)$ & $2.54(0.05)$ & 0.28 & 6.05 & $\mathrm{sm}$ \\
\hline \multirow[t]{2}{*}{ No. 27) } & VII & $5.23(0.20)$ & $2.51(0.16)$ & 0.29 & 5.76 & $\mathrm{sm}$ \\
\hline & VIII & $4.90(0.26)$ & $2.69(0.17)$ & 0.27 & 5.40 & $\mathrm{sm}$ \\
\hline
\end{tabular}

Notes. CL - chromosome length, mean value (standard deviation); $r$ - arm ratio, mean value (standard deviation); $\mathrm{Cl}$ - centromeric index; $\mathrm{RL}$ relative chromosome length; $\mathrm{m}$ - metacentric chromosome; sm - submetacentric chromosome.

In general, other representatives of the genus Adonis also equally include isobrachial and heterobrachial chromosomes in the set. For instance, the karyotype formula for A. vernalis L. (Schrager \& Malakhova, 1981) was $2 n=2 x=16=8 \mathrm{~m}+8 \mathrm{sm}$, and for $A$. 
brevistyla Franch. it was $2 n=2 x=16=8 m+2 s m+6 s t$ (Yang, 2001). Similar formulas were obtained for $A$. distorta Ten. (Del Grosso \& Pogliani, 1971) and A. multiflora Nishikawa \& Koji Ito (Ikeda et al., 2006). This is probably the general pattern of karyotype in the genus Adonis. Differences between species relate primarily to the degree of asymmetry of heterobrachial chromosomes.

An additional parameter characterizing the chromosome set is the genome size (nuclear DNA content, or 2C-value). We have determined absolute nuclear DNA content for most of the studied populations of both species (Table 1; Fig. 3). The values varied slightly between the plants of diverse populations within the species. Absolute nuclear DNA content in Adonis amurensis was higher (from $20.05 \pm 0.92$ to $20.71 \pm 1.20 \mathrm{pg}$ ) than that in $A$. apennina (from $16.96 \pm 0.50$ to $17.67 \pm 0.62 \mathrm{pg}$ ), even though the total chromosome length of the set was close. This is obviously due to higher condensation of the $A$. amurensis chromosomes compared to A. apennina.


m m

m

m

sm sm

sm sm
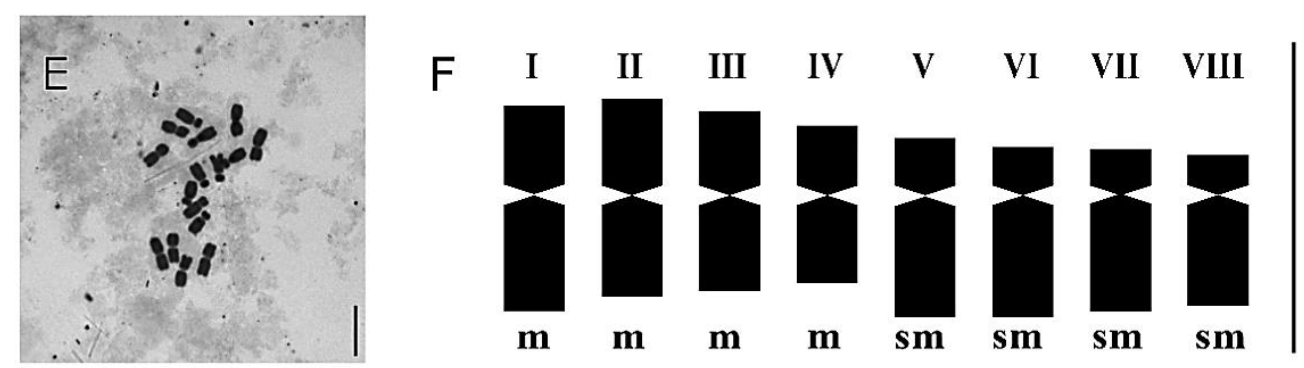

Fig. 2. Mitotic metaphase plates (A, C, E) and haploid idiograms (B, D, F): A, B - Adonis amurensis (Amur Oblast'), $2 n=16$; C, D - Adonis apennina (Altai Republic, No. 31), $2 n=16 ; \mathbf{E}, \mathbf{F}-$ Adonis apennina (Irkutsk Oblast', No. 27 ), $2 n=16$. I-VIII - chromosome pairs; $\mathrm{m}$ - metacentric chromosome; sm - submetacentric chromosome. Scale bars $=10 \mu \mathrm{m}$.

Table 3. Karyotype parameters of Adonis amurensis and Adonis apennina.

\begin{tabular}{|c|c|c|c|c|c|c|c|c|c|}
\hline Species & $P L$ & $2 n$ & $\mathrm{KF}$ & THL & $\begin{array}{l}\text { Mean } \\
\mathrm{CL}\end{array}$ & $\mathrm{CV}_{\mathrm{CL}}$ & $\mathrm{CV}_{\mathrm{Cl}}$ & $\mathrm{M}_{\mathrm{CA}}$ & $\mathrm{KA}$ \\
\hline $\begin{array}{c}\text { Adonis amurensis } \\
\text { (Amur Oblast') }\end{array}$ & $2 x$ & 16 & $8 m+8 s m$ & $\begin{array}{l}44.07 \\
(1.76)\end{array}$ & $\begin{array}{c}5.51 \\
(0.46)\end{array}$ & $\begin{array}{c}8.38 \\
(0.37)\end{array}$ & $\begin{array}{l}18.62 \\
(0.84)\end{array}$ & $\begin{array}{l}20.35 \\
(0.82)\end{array}$ & $2 \mathrm{~A}$ \\
\hline $\begin{array}{c}\text { Adonis apennina } \\
\text { (Altai Republic, } \\
\text { No. 31) }\end{array}$ & $2 x$ & 16 & $8 m+8 s m$ & $\begin{array}{l}41.94 \\
(1.80)\end{array}$ & $\begin{array}{c}5.24 \\
(0.59)\end{array}$ & $\begin{array}{l}11.15 \\
(1.76)\end{array}$ & $\begin{array}{l}24.17 \\
(1.12)\end{array}$ & $\begin{array}{l}23.99 \\
(0.50)\end{array}$ & $3 A$ \\
\hline $\begin{array}{c}\text { Adonis apennina } \\
\text { (Irkutsk Oblast', } \\
\text { No. } 27 \text { ) }\end{array}$ & $2 x$ & 16 & $8 m+8 s m$ & $\begin{array}{l}45.39 \\
(1.17)\end{array}$ & $\begin{array}{c}5.67 \\
(0.61)\end{array}$ & $\begin{array}{l}10.81 \\
(1.55)\end{array}$ & $\begin{array}{l}23.60 \\
(0.99)\end{array}$ & $\begin{array}{l}24.98 \\
(0.53)\end{array}$ & $3 A$ \\
\hline
\end{tabular}

Notes. PL - ploidy level; $2 n$ - somatic chromosome number; $\mathrm{THL}$ - total haploid length; Mean $\mathrm{CL}$ - mean chromosome length; $\mathrm{CV}_{\mathrm{CL}}$ - Coefficient of Variation of Chromosome Length; $\mathrm{CV}_{\mathrm{CI}}$ - Coefficient of Variation of Centromeric Index; $\mathrm{M}_{\mathrm{CA}}-\mathrm{Mean}$ Centromeric Asymmetry; $\mathrm{KA}$ - Stebbins asymmetry index; $\mathrm{m}$ - metacentric chromosome; sm - submetacentric chromosome. 


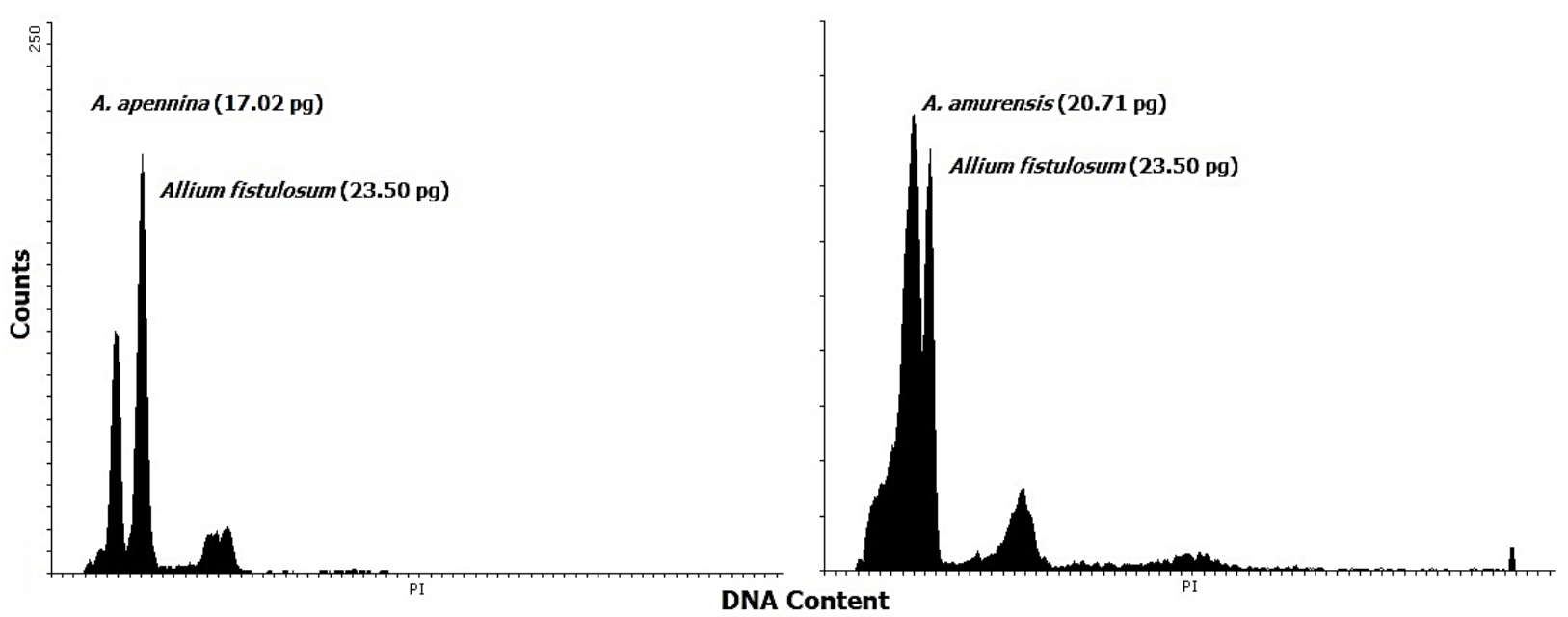

Fig. 3. Flow cytometric histograms of: A - Adonis apennina (Khakassia Republic, Ordzhonikidze Raion, No. 7.1); B - Adonis amurensis (Sakhalin Oblast', Kunashir Island). Allium fistulosum L. was used as an internal standard.

\section{Conclusion}

Thus, the Adonis apennina chromosome set is conservative in both chromosome morphology and nuclear DNA content over at least a significant part of the areal. Adonis amurensis is a more polymorphic species, at least in its ploidy level.

\section{Acknowledgments}

The study was supported by RFBR (research project No. 20-54-53008), the Ministry of Science and Higher Education of the Russian Federation (project No. FZMW-2020-0003), and the National Natural Science Foundation of China (No. 32011530072). The authors are grateful to Roman Annenkov for making Fig. 2.

\section{References}

Altinordu F., Peruzzi L., Yu Y., He X. (2016) A tool for the analysis of chromosomes: KaryoType. Taxon, 65(3), 586-592.

Cronquist A. (1981) An integrated system of classification of flowering plants. Columbia Univ. Press, New York.

Del Grosso F., Pogliani M. (1971) Studio cariologico di Adonis distortus Ten. Biogeographia - The Journal of Integrative Biogeography, 2(1), 69-79. DOI: 10.21426/B62110466

Doležel J., Sgorbati S., Lucretti S. (1992) Comparison of three DNA fluorochromes for flow cytometric estimation of nuclear DNA content in plants. Physiologia Plantarum, 85, 625-631. DOI: 10.1111/j.1399-3054.1992.tb04764.x

Erst A. S., Sukhorukov A. P., Mitrenina E. Yu., Skaptsov M. V., Kostikova V. A., Chernisheva O. A., Troshkina V. I., Kushunina M., Krivenko D. A., Ikeda H., Xiang K., Wang W. (2020) An integrative taxonomic approach reveals a new species of Eranthis (Ranunculaceae) in North Asia. PhytoKeys, 140, 75-100. DOI: 10.3897/phytokeys.140.49048

Greilhuber J., Doležel J., Lysák M. A., Bennett M. D. (2005) The origin, evolution and proposed stabilization of the terms' Genome Size' and 'C-Value' to describe nuclear DNA contents. Annals of Botany, 95(1), 255-260. DOI:10.1093/aob/mci019

Ikeda H., Tsusaka M., Kaneko Sh., Kariyama Sh. (2006) A new locality of Adonis multiflora (Ranunculaceae) and its karyomorphology. Journal of Phytogeography and Taxonomy, 54, 65-69.

Kurita M. (1955) Cytological studies in Ranunculaceae IV. The karyotype analysis in Actaea and some other genera. Jap. Jour. Genet, 30, 124-127.

Langlet O. (1932) Über chromosomenverhältnisse und systematik der Ranunculaceae. Svensk Botanisk Tidskrift, 26, $381-400$.

Lavrenko A. N., Serditov N. P. (1985) Karyosystematic study of Ranunculaceae and Paeoniaceae in the north-east of the European part of the USSR. Bot. Zhurn. SSSR, 70(10), 1346-1354. [in Russian].

Lee Y. N. (1967) Chromosome numbers of flowering plants in Korea. J. Korean Res. Inst. Ewha Women's Univ, 11, $455-478$.

Levan A., Fredga K., Sandberg A. (1964) Nomenclature for centrometric position of chromosomes. Hereditas, 52, $201-220$.

Luferov A. N. (2004) Taxonomic synopsis of buttercups (Ranunculaceae Juss.) of the Far East of Russia. Turczaninowia, 7 (1), $5-$ 84 [In Russian].

Luferov A. N. (2018) Genus Adonis L. Flora of the Lower Volga region. V. 2: Dicotyledonous flowering plants. Part 1. SalicaceaeDroseraceae. Resp. ed. N. M. Reshetnikov; Main Botanical Garden named after N.V. Tsitsin RAS. M .: KMK Scientific Publishing Association. 347-350 [In Russian].

Luferov A. N. (2020) On the diagnosis of species Adonis L. (Ranunculaceae) of the flora of Russia. The latest foreign and domestic preparations, 2, 3-14 [In Russian]. DOI: 10.33920/med-06

Mitrenina E. Yu., Erst A. S., Skaptsov M. V., Kutsev M. G., Kuznetsov A. A. (2020) Karyotypes and nuclear DNA content in some Trollius L. and Hegemone Bunge ex Ledeb. (Ranunculaceae) species of Asian Russia and China. Turczaninowia, 23(1), 90-98 [In Russian]. DOI: 10.14258/turczaninowia.23.1.9

Meusel H., Jaeger E., Weinert E. (1965) Vergleichende Chorologie der Zentraleuropaischen Flora. Stuttgart. G. Fischer.

Nishikawa T. (1989) Botanical studies on Adonis amurensis Regel et Radde in Japan (part 2). J. Hokkaido Univ. Educ., Sect. 2B, $39(2), 1-25$. 
Nishikawa T., Ito K. (1979) The chromosome numbers of Adonis amurensis Regel \& Radde (sensu lato) of northern Honshu. J. Jap. Bot., 54(12), 353-362.

Nishikawa T., Kadota Y. (2006) Adonis. In: Flora of Japan. V. Ila. (Iwatsuki K. et al., eds.). Kodansha Ltd., Tokyo. $287-288$.

Parfitt B. D. (1997) Adonis L. In: Flora of North America Committee, eds. Flora of North America. V. 3. Magnoliophyta: Magnoliidae and Hamamelidae. Oxford University Press, Oxford. 184-187.

Paszko A. (2006) A critical review and a new proposal of karyotype asymmetry indices. PI. Syst. Evol., 258, 39-48. DOI: 10.1007/s00606-005-0389-2

Peruzzi L., Eroğlu H. E. (2013) Karyotype asymmetry: Again, how to measure and what to measure? Comparative Cytogenetics, 7, 1-9. DOI: 10.3897/compcytogen.v7i1.4431

Poshkurlat A. P. (2000) The genus Adonis L. Systematics, distribution, biology. Moscow, Nauka [In Russian].

Ren Y., Chang H.L., Tian X.H., Song P., Endress P.K. (2009) Floral development in Adonideae (Ranunculaceae). In: Flora. 204, 506517.

Rice A., Glick L., Abadi Sh., Einhorn M., Kopelman N.M., Salman-Minkov A., Mayzel J., Chay O., Mayrose I. (2015) The Chromosome Counts Database (CCDB) - a community resource of plant chromosome numbers. New Phytologist, 206(1), 19-26. http://ccdb.tau.ac.il/

Ricroch A., Yockteng R., Brown S. C., Nadot S. (2005) Evolution of genome size across some cultivated Allium species. Genome, 48, 511-520. DOI: 10.1139/g05-017

Sennikov A. (1998) Notulae taxonomicae et nomenclatoricae de taxis nonnullis et generibus Adonis L. (Ranunculaceae), Linum L. (Linaceae), Adenophora Fisch. (Campanulaceae) et Hypericum L. (Hypericaceae). Novitates Systematicae Plantarum Vascularum, 31, 81-91.

Shlangena Z. E. (1976) The chromosome numbers of some Adonis L. species in the USSR (Ranunculaceae). Bot. Zhurn. (Moscow \& Leningrad), 61(11), 1603-1608 [In Russian].

Shrager L. N. (1980) The polymorphism of satellite chromosomes of several populations of Adonis sibirica Patr. Problems of population and evolutionary cytogenetics of plants and animals. Tomsk University Publishing House, Tomsk, 51-56 [In Russian].

Shrager L. N., Malakhova L. A. (1978) Karyotypical studies of Adonis sibirica Patr. In Tomsk region. Cytologia, 20(5), 592-596 [In Russian].

Schrager L. N., Malakhova L. A. (1981) An analysis of karyotypes of Adonis vernalis and Clematis integrifolia (Ranunculaceae). Bot. Zhurn. (Moscow \& Leningrad), 66(3), 438-440 [In Russian].

Smirnov S., Skaptsov M., Shmakov A., Fritsch R., Friesen N. (2017) Spontaneous hybridization among Allium tulipifolium and A. robustum (Allium subg. Melanocrommyum, Amaryllidaceae) under cultivation. Phytotaxa, 303(2), 155-164. DOI: 11646/phytotaxa.303.2.5

Smirnov Yu. A. (1968) Accelerated method for studying somatic chromosomes in fruit trees. Tsitologia, 10(12), 1601-1602 [In Russian].

Son D. Ch., Park B. K., Ko S. Ch. (2016) Phylogenetic study of the section Adonanthe of genus Adonis L. (Ranunculaceae) based on ITS sequences. Korean Journ. Plant Taxonomy, 46(1), 1-12. DOI: 10.11110/kjpt.2016.46.1.1

Starodubtsev V. N. (1985) Chromosome numbers in the representatives of some families from the Soviet Far East. Bot. Zhurn. SSSR, 70(2), 275-277 [In Russian].

Starodubtsev V. N. (1989) Chromosome numbers in the species of the families Aceraceae, Brassicaceae, Cyperaceae, Euphorbiaceae, Papaveraceae and Ranunculaceae from the Soviet Far East. Bot. Žhurn. (Moscow \& Leningrad), 74(11), 16741675 [In Russian].

Stebbins G. L. (1971) Chromosomal evolution in higher plants. London: Arnold.

Tamura M. (1991) A new classification of the family Ranunculaceae 2. Acta Phytotaxonomica et Geobotanica, 42, 177-187 [In Japanese].

Volkova S. A., Gorovoy P. G., Pshennikova L. M. (2020) Karyotypes of Adonis amurensis (Ranunculaceae) in the Primorsky Territory and in Sakhalin. Turczaninowia, 23(2), 39-48. DOI: 10.14258/turczaninowia.23.2.6 [In Russian].

Wang L.-Z., Liu M.-Y. (1988) Studies on the genus Adonis in Northeast China. Bull. Bot. Res. Harbin, 8, 49-52.

Wang W. T. (1994a) Revision of Adonis (Ranunculaceae) (1). Bull. Bot. Research, 14(1), 1-31.

Wang W. T. (1994b) Revision of Adonis (Ranunculaceae) (2). Bull. Bot. Research, 14(2), 105-138.

Yang Q.-E. (2001) Cytology of eleven species in the genus Ranunculus L. and five in its four related genera from China. Acta Phytotaxonomica Sinica, 39, 405-422.

\section{Citation:}

Mitrenina, E.Yu., Erst, A.S., Skaptsov, M.V., Leonova, T.V., Veklich, T.N., Chernysheva, O.A., Luferov, A.N., Wang, W. (2021). Karyotypes and genome size of Adonis amurensis and Adonis apennina (Ranunculaceae) from Asian Russia. Ukrainian Journal of Ecology, 11 (1), $163-170$.

(cc) $\mathbf{E Y}$ This work is licensed under a Creative Commons Attribution 4.0. License 